VOTE OF CONVOCATION ON THE COWPER COMMISSION SCHEME.

A NOTHER step has been taken in the long contro$A$ versy with respect to the equipment of the University of London with teaching functions. While the other bodies represented on the recent deputation to the Duke of Devonshire had passed resolutions asking the Government to introduce a Bill similar to Lord Playfair's "London University Commission Bill, 1895," but with an added clause giving a right of appeal to the Privy Council (Nature, December 5, i895), Convocation had not expressed any opinion either on the Bill or on the proposed appeal, owing to Lord Playfair's Bill being introduced into the House of Lords too late to allow of a resolution approving its terms to be moved at the last meeting in May. On Tucsday last, the Annual Committee recommended Convocation to adopt the following resolution: "That this House desires the early introduction into Parliament of a Bill for the reconstitution of the University similar to that introduced last year by Lord Playfair, but with an inserted clause securing to the Senate, to Convocation, and to other bodies affected, the right of appeal to the Privy Council on any of the provisions which may hereafter be settled by the Statutory Commission." This resolution was carried by 470 votes against 244 , and thus for the third time Convocation, in the only legal way, has pronounced decisively in favour of the Cowper Commission scheme. The progressive rise in the majorities is not the least satisfactory feature of the struggle in Convocation-a majority of 24 in a house of 290 in January of last year rose to $\mathrm{J} 22$ in a house of 354 in May, and has now become 226 in a house of 714 . The next step rests with the Government, but in view of the remarkable unanimity existing among the bodies affected by the scheme, and the universally favourable attitude of the metropolitan press towards it, we can be in no doubt as to what the final settlement must be.

\section{ON A NEW KIND OF RAYS.1}

I) $\mathrm{A}$ DISCHARGE from a large induction coil is passed through a Hittorf's vacuum tube, or through a well-exhausted Crookes' or Lenard's tube. The tube is surrounded by a fairly close-fitting shield of black paper; it is then possible to see, in a completely darkened room, that paper covered on one side with barium platinocyanide lights up with brilliant fluorescence when brought into the neighbourhood of the tube, whether the painted side or the other be turned towards the tube. The fluorescence is still visible at two metres distance. It is easy to show that the origin of the fluorescence lies within the vacuum tube.

(2) It is seen, therefore, that some agent is capable of penetrating black cardboard which is quite opaque to ultra-violet light, sunlight, or arc-light. It is therefore of interest to investigate how far other bodies can be penetrated by the same agent. It is readily shown that all bodies possess this same transparency, but in very varying degrees. For example, paper is very transparent; the fluorescent screen will light up when placed behind a book of a thousand pages ; printer's ink offers no marked resistance. Similarly the fluorescence shows behind two packs of cards; a single card does not visibly diminish the brilliancy of the light. So, again, a single thickness of tinfoil hardly casts a shadow on the screen; several have to be superposed to produce a marked effect. Thick blocks of wood are still transparent. Boards of pine two or three centimetres thick absorb only very little. A piece of sheet aluminium, 15 $\mathrm{mm}$. thick, still allowed the X-rays (as I will call the rays,

1 By W. C. Röntgen. Translated by Arthur Stanton fám the Sitzungs berichte der Würaburger Physik $\rightarrow$ medic. Gesellschaft, 1895 .

No. I 369 , vOI.. 53] for the sake of brevity) to pass, but greatly reduced the fluorescence. Glass plates of similar thickness behave similarly; lead glass is, however, much more opaque than glass free from lead. Ebonite several centimetres thick is transparent. If the hand be held before the fluorescent screen, the shadow shows the bones darkly, with only faint outlines of the surrounding tissues.

Water and several other fluids are very transparent. Hydrogen is not markedly more permeable than air. Plates of copper, silver, lead, gold, and platinum also allow the rays to pass, but only when the metal is thin. Platinum $2 \mathrm{~mm}$. thick allows some rays to pass ; silver and copper are more transparent. Lead ${ }^{\circ} \cdot 5 \mathrm{~mm}$. thick is practically opaque. If a square rod of wood $20 \mathrm{~mm}$. in the side be painted on one face with white lead, it casts little shadow when it is so turned that the painted face is parallel to the X-rays, but a strong shadow if the rays have to pass through the painted side. The salts of the metals, either solid or in solution, behave generally as the metals themselves.

(3) The preceding experiments lead to the conclusion that the density of the bodics is the property whose variation mainly affects their permeability. At least no other property seems so marked in this connection. But that the density alone does not determine the transparency is shown by an experiment wherein plates of similar thickness of Iceland spar, glass, aluminium, and quartz were employed as screens. Then the Iceland spar showed itself much less transparent than the other bodies, though of approximately the same density. I have not remarked any strong fluorescence of Iceland spar compared with glass (see below, No. 4).

(4) Increasing thickness increases the hindrance offercd to the rays by all bodies. A picture has been impressed on a photographic plate of a number of superposed layers of tinfoil, like steps, presenting thus a regularly increasing thickness. This is to be submitted to photometric processes when a suitable instrument is available.

(5) Pieces of platinum, lead, zinc, and aluminium foil were so arranged as to produce the same weakening of the effect. The annexed table shows the relative thickness and density of the equivalent sheets of metal.

\begin{tabular}{|c|c|c|c|c|c|c|}
\hline & Thickne & & Relativ & thick & ess. & 1)ensity \\
\hline Platinum & 018 & $\mathrm{~nm}$. & $\cdots$ & I & $\cdots$ & $21 \cdot 5$ \\
\hline Lead ............. & .050 & , , & $\ldots$ & 3 & $\ldots$ & $\mathrm{II}^{\circ} \cdot 3$ \\
\hline Zinc $\ldots . . . . . .$. & 100 & , & ... & 6 & $\ldots$ & $7 \cdot \mathbf{I}$ \\
\hline Aluminium...... & $3 \cdot 500$ & , , & $\cdots$ & 200 & $\cdots$ & $2 \cdot 6$ \\
\hline
\end{tabular}

From these values it is clear that in no case can we obtain the transparency of a body from the product of its density and thickness. The transparency increases much more rapidly than the product decreases.

(6) The fluorescence of barium platinocyanide is not the only noticeable action of the X-rays. It is to be observed that other bodies exhibit fluorescence, e.g. calcium sulphide, uranium ylass, Iceland spar, rock-salt, \&c.

Of special interest in this connection is the fact that photographic dry plates are sensitive to the X-rays. It is thus possible to exhibit the phenomena so as to exclude the danger of error. I have thus confirmed many observations originally made by eye observation with the fluorescent screen. Here the power of the X-rays to pass through wood or cardboard becomes useful. The photographic plate can be exposed to the action without removal of the shutter of the dark slide or other protecting case, so that the experiment need not be conducted in darkness. Manifestly, unexposed plates must not be left in their box near the vacuum tube.

It seems now questionable whether the impression on the plate is a direct effect of the X-rays, or a secondary result induced by the fluorescence of the material of the plate. Films can receive the impression as well as ordinary dry plates. 